Prof. Bonney described specimens brought by Col. Feilden from Norway, the Kola Peninsula; and Novaya Zemlya. From an examination of the rocks obtained in situ in the last-mentioned region, Prof. Bonney confirms Col. Feilden's suggestion that the Kolguev erratics may have come from Novaya Zemlya.

2. "Extrusive and Intrusive Igneous Rocks as Products of Magmatic Differentiation." By Prof. J. P. Iddings, For. Corr. G.S.

The author, after pointing out the propositions concerning differentiation of magmas upon which he is in agreement with Prof. Brögger, discusses the points of difference, and describes the relation of the igneous rocks at Electric Peak to all of those which took part in the great series of eruptions which occupied almost the whole Tertiary period, and spread themselves over a vast territory in Montana, Wyoming, and Idaho. In Tertiary times the eruptions were at first largely explosive, and the accumulation of tuff-breccia formed a chain of lofty volcanoes, comparable with the Andes in size as well as in the nature of their material (andesite and andesitic basalt). After considerable erosion of these volcanoes, gigantic fissure eruptions flooded the region west of the denuded volcanoes. The massive Java-streams which welled from these fissures consisted at first of rhyolite with an average silica-percentage of about 74, alternating occasionally with basalt; but the great bulk of the basalt was poured out immediately after the rhyolite from fissures still farther to the west and south-west. In the case of these extrusive rocks, whose volumes are of such magnitude, the evidence drawn from the succession of their eruptions and from their composition is of a higher order than that derived from the smaller and more localized eruptions; and it is upon evidence of this order that the author ventured to enunciate the principle that in a region of eruptive activity the succession of eruptions in general commences with magmas representing a mean composition and ends with those of extreme composition.

\title{
COREFSPONDEITOE.
}

\section{MR. DUGALD BELL AND THE PARALLEL ROADS OF GLENROY.}

SIr,-Did time allow, it would be easy to show that Mr. Dugald Bell's criticism of my remarks on the Parallel Roads of Glenroy (page 319) is a typical instance of forensic advocacy. But I am leaving England for the Alps, so that Lochaber must rest in peace. Whether on my return it will be worth while spending time in travelling over well-worn paths, is a doubtful matter. Nothing can be settled about Glenroy till some fresh evidence turns up. Meanwhile Mr. Dugald Bell may rest assured that I am not frightened at being in a minority. I have lived and been a geologist long enough to have watched the apparition and the fading away of many Brocken-spectres, not in our science only.

July $3 r d, 1896$.

T. G. BONney. 